\title{
Study of Flow Pattern in Jet Clarifier for Removal of Turbidity by Residence Time Distribution Approach
}

\author{
Ploypailin Romphophak ${ }^{1, a, *}$, Kritchart Wongwailikhit ${ }^{1}$, Nattawin Chawaloesphonsiya ${ }^{1}$, \\ Pornsak Samornkraisorakit ${ }^{2}$, and Pisut Painmanakul ${ }^{1,3, b}$ \\ 1 Department of Environmental Engineering, Faculty of Engineering, Chulalongkorn University, Bangkok \\ 10330, Thailand \\ 2 Metropolitan Waterworks Authority, Bangkok 10210, Thailand \\ 3 Research Unit Control of Emerging Micropollutants in Environment, Chulalongkorn University, \\ Bangkok 10330, Thailand \\ E-mail: ar.ploypailin@gmail.com (Corresponding author), bpisut114@hotmail.com
}

\begin{abstract}
This study aims to determine the performance of the jet clarifier for turbidity removal and its mechanisms for proposing the optimal operating conditions and design criteria. The experiment were performed continuously using a pilot scale jet clarifier with the volume of $243 \mathrm{~L}$. Effects of liquid flow rates, types of liquid phase, and sludge blanket heights on turbidity removal efficiency were investigated. Moreover, the residence time distribution (RTD) study was carried out to investigate the flow pattern. The results indicated that the jet clarifier can effectively reduce the turbidity of the synthetic water with the efficiency of $80 \%$ under the optimal condition. The RTD results suggested that the flow pattern in the jet clarifier corresponded to the design as the plug flow and mixed flow conditions were found in the coagulation and the flocculation/sedimentation zones, respectively. The presence of the sludge blanket can reduce the bypass and recirculated flows. Besides, the increase of flow rate resulted in the increase recirculation in the tank. It can be suggested that the jet clarifier can be used for removing turbidity in the water treatment. The hydrodynamic in the reactor, which relates to flow pattern in the reactor, is one among the important factors in a jet clarifier.
\end{abstract}

Keywords: Jet clarifier, turbidity removal, residence time distribution (RTD).

ENGINEERING JOURNAL Volume 20 Issue 2

Received 21 September 2015

Accepted 19 November 2015

Published 18 May 2016

Online at http://www.engj.org/

DOI:10.4186/ej.2016.20.2.17 


\section{Introduction}

The jet clarifier is a type of solid contact clarifier considered as an effective and compact system for water treatment [1]. It can be implied as sludge recirculation units with a static mixer for destabilization. This system consists of two sections including mixing and settling zones. At the mixing zone, raw water is mixed with coagulants and injected through the centre of the reactor. Flocculation occurs as destabilized particles would aggregate into floc during flowing upward. Flocs can be separated in a settling zone and deposit forming a sludge blanket. Afterwards, sludge was separated from the clarified water in a settling zone where sludge is deposited and recirculated through the central zone by the induced zone. According from this process, the enrichment can induce the rapid flocculation and the formation of a dense precipitates. Moreover, the jet clarifier is also comprised of a sludge hopper in order to eliminate the excess sludge [1-3]. Consequently, hydrodynamical modelling of jet clarifier is highly important, at least from the following two perspectives: because of its influence on the performance of a given plant and because of its role in scalingup from pilot tests.

Modern methods, residence time distribution (RTD) were developed and applied to predict hydrodynamic behaviors in reactor [4]. The measurement is obtained from tracer experiment that consists of an impulse response method. The injection of a tracer is conducted at the system inlet and a probe is introduced at the outlet to record the concentration-time relation [5]. The relationship can be used to construct the exit age distribution in reactor, which indicates the flow pattern in reactor. The different regions of a reactor can be modeled as that of mix flow or plug flow reactor having dead spaces with bypassing between zones [4]. The determination of RTD is frequently combined with the modelling of the system using one, two or three-parameter models, either based in mass balance or in statistical analysis $[6,7]$. Therefore, RTD measurement can be an efficient tool for better understanding the hydrodynamic condition in the reactor. This information can be applied for designing reactor as well as scale-up, operation, and optimization $[7,8]$.

The objectives of this work were to determine the performance of jet clarifier for turbidity removal in the aspect of water treatment. Effects of flow rates, sludge blanket height, and water types were investigated. The flow behaviour in the reactor was also analysed by the RTD. The information obtained from this work could be utilized for designing the reactor design and suggesting the appropriate operation for a jet clarifier.

\section{Materials and Methods}

\subsection{Liquid Phases}

The liquid phases were the synthetic raw water and the real surface raw water from Prapa canal along Samsen Water Treatment Plant. The synthetic water was prepared by mixing bentonite used as model colloidal particles with tap water. To simulate the real raw water, the initial turbidity was adjusted to $50 \pm 1$ NTU, which equals the average raw water turbidity of the Samsen plant [9]. The stock synthetic raw water was stirred by an agitator to ensure that the bentonite particles were dispersed thoroughly.

\subsection{Experiment Set-up}

The reactor was made from an acrylic material with the dimension as presented in Table 1. Figure 1 shows a cross-section of the jet clarifier and a schematic diagram of hydrodynamics.

\subsection{Experimental Procedures}

The jet clarifier was operated continuously in both two parts of the experiments. The first part was to study the turbidity removal efficiency of the jet clarifier. Aluminum sulfate $\left(\mathrm{Al}_{2}\left(\mathrm{SO}_{4}\right)_{3} \cdot 18 \mathrm{H}_{2} \mathrm{O}\right)$ was used as coagulant. The optimal coagulant dosage from the jar test experiment was applied. The synthetic or surface raw water was fed from the water preparation tank to mix with the coagulant injected by a diaphragm pump and flow through the reactor. Effects of liquid flow rates on the removal efficiency at the steady state were determined. For the second part, the residence time distribution (RTD) of the reactor was studied using sodium chloride $(\mathrm{NaCl})$ solution with the concentration of $30 \mathrm{~g} / \mathrm{L}$ and $300 \mathrm{ml}$ as the tracer for a pulse injection. 
Table 1. Pilot column dimensions.

\begin{tabular}{ccc}
\hline \multicolumn{1}{c}{ Dimensions } & Measurement units & Value \\
\hline Flocculation zone 1: Conical shape & volume (L) & 37 \\
- Truncated cone height & $\mathrm{m}$ & 0.65 \\
- Diameter of truncated cone at base & $\mathrm{m}$ & 0.10 \\
- Diameter of truncated cone at top & $\mathrm{m}$ & 0.30 \\
\hline Flocculation zone 2: Cylindrical shape & volume (L) & 36 \\
- Height & $\mathrm{m}$ & 0.80 \\
- Diameter & $\mathrm{m}$ & 0.40 \\
\hline Sedimentation zone & volume (L) & 171 \\
- Truncated cone height & $\mathrm{m}$ & 0.30 \\
- Diameter of truncated cone at base & $\mathrm{m}$ & 0.18 \\
- Diameter of truncated cone at top & $\mathrm{m}$ & 0.70 \\
- Cylindrical height & $\mathrm{m}$ & 0.50 \\
- Cylindrical diameter & $\mathrm{m}$ & 0.70 \\
\hline
\end{tabular}

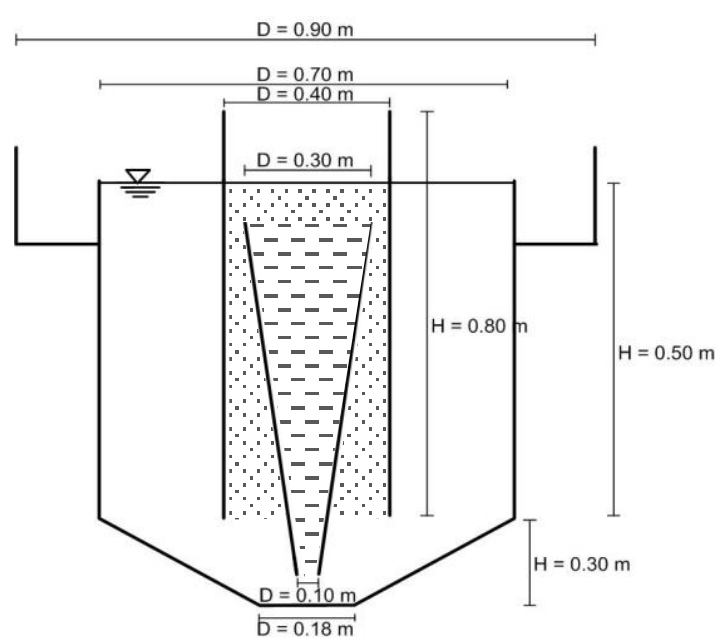

a) Cross-section of Jet clarifier

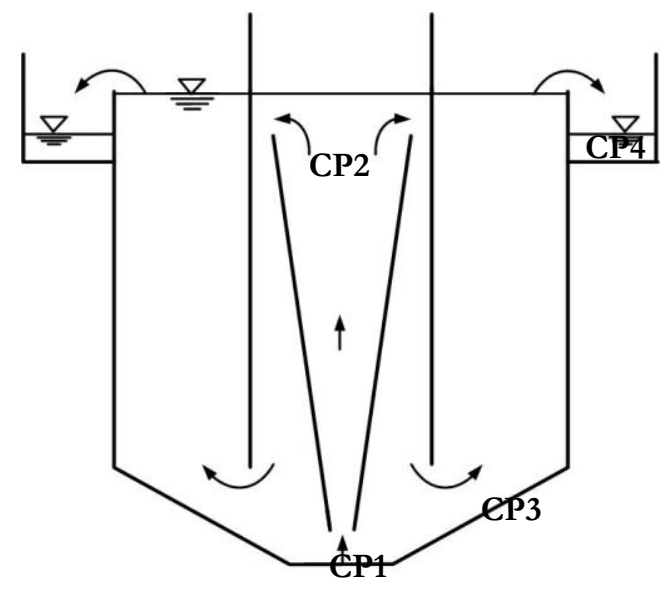

b) Schematic diagram of hydrodynamics

Where; $-{ }_{--}$Flocculation zone 1

Flocculation zone 2

Sedimentation zone

Fig. 1. Jet clarifier in this work.

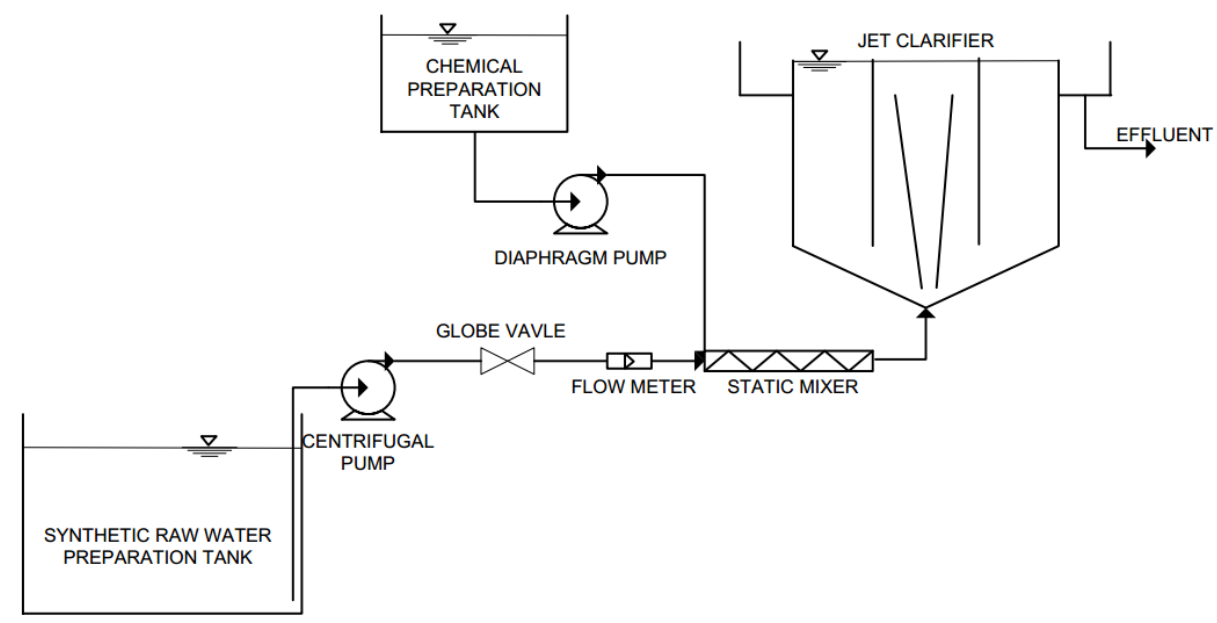

Fig. 2. Schematic diagram of jet clarifier process. 


\subsection{Operating Conditions of Jet Clarifier}

The system can be divided into 2 parts including the rapid mixing by the static mixer and the slow mixing followed by the sedimentation in the jet clarifier. The retention time from each part at different flow rates is compared with those from the conventional processes for turbidity removal as shown in Table 2. The designed retention time of the jet clarifier was in the same range with the criteria. Note that $G$ values in the static mixer and the jet clarifier were controlled by the liquid flow rates, while the gradient in the jar test were kept constant.

Table 2. Comparison of contact or retention time of the jet clarifier to the design criteria.

\begin{tabular}{cccccc}
\hline Category & $\begin{array}{c}\text { Flow rate } \\
(\mathbf{L} / \mathbf{h r})\end{array}$ & $\begin{array}{c}\text { Coagulation } \\
\text { time (s) }\end{array}$ & $\begin{array}{c}\text { Flocculation } \\
\text { time (min) }\end{array}$ & $\begin{array}{c}\text { Sedimentation } \\
\text { time (hr) }\end{array}$ & Reference \\
\hline Design & - & $1<\mathrm{t}<5$ & $20-40$ & $1-3$ & {$[1,10,11,12]$} \\
criteria & & 3.31 & 50 & 4.66 & \\
& 40 & 2.65 & 40 & 3.72 & \\
Jet clarifier & 50 & 1.89 & 30 & 2.79 & \\
& 70 & 1.20 & 20 & 1.86 & \\
& 110 & 0.74 & 13.16 & 1.25 & \\
\hline
\end{tabular}

\subsection{Analytical Methods}

The turbidity and $\mathrm{pH}$ were measured by the turbidity meter (Lovibond, Germany) and the $\mathrm{pH}$ meter (Hach, USA), respectively. The standard methods $2540 \mathrm{D}$ and $2320 \mathrm{~B}$ were applied for analysing suspended solid and alkalinity [13]. The turbidity removal efficiency was evaluated from Eq. (1).

$$
\text { Turbidity removal }(\%)=\left(\frac{C_{i}-C_{f}}{C_{i}}\right) \times 100
$$

The considered parameters in this work can be calculated by Eq. (2) - (5) in Table 3.

Table 3. Parameters in jet clarifier experiments.

\begin{tabular}{ccccc}
\hline System & Parameter & Equation & Equation no. & Reference \\
\hline & $G_{\text {static mixer }}$ & $G=\sqrt{\frac{h_{\mathrm{f}} \times g \times \rho}{\mu \times t}}$ & $(2)$ & {$[14]$} \\
\cline { 2 - 5 } Jet clarifier & $\mathrm{t}_{\text {static mixer }}$ & $\mathrm{t}=\frac{\text { Static mixer length }(\mathrm{m})}{\mathrm{V}\left(\frac{\mathrm{m}}{\mathrm{s}}\right)}$ & $(3)$ & {$[14]$} \\
\cline { 2 - 5 } & $\mathrm{G}_{\text {Fludized bed }}$ & $\mathrm{G}=\sqrt{\frac{\mathrm{g}\left(\rho_{\mathrm{s}}-\rho\right) \mathrm{Cu}}{\mu}}$ & $(4)$ & {$[15]$} \\
\cline { 2 - 5 } & $\mathrm{t}_{\text {theoretical }}$ & $\mathrm{t}=\frac{\mathrm{V}}{\mathrm{Q}}$ & $(5)$ & {$[11,12]$} \\
\hline
\end{tabular}

The residence time distribution (RTD) was conducted for analyzing the behavior of non-ideal reactors. Two single parameter flow model was used to characterize the RTD results. Although other analysis methods are available, the compartment model and the dispersion model were chosen due to their simplicity and applicability [16]. The method of moments and non-ideal device techniques were used to calculate the parameters from the experimental data, including mean residence time $\left(\mathrm{t}_{\mathrm{m}}\right)$, variance $\left(\sigma^{2}\right)$, exact variance $\left(\sigma_{\theta}^{2}\right)$ and flow model parameter $[17,18]$. The tracer $(\mathrm{NaCl})$ pulse input data are presented using the exit-age distribution function $E(t)$ which is defined as the fraction of material which has left the device between time $t$ and $t+d t$. The function $E(t)$ with the unit of min $^{-1}$ can be expressed as

$$
\text { Resident Time Distribution; } \mathrm{E}(\mathrm{t})=\frac{\mathrm{C}_{(\mathrm{t})}}{\int_{0}^{\infty} \mathrm{C}_{(\mathrm{t})} \mathrm{dt}}
$$


where $C(t)$ is the concentration of the tracer at time $t$. The mean residence time $\left(\mathrm{t}_{\mathrm{m}}\right)$ and variance $\left(\sigma^{2}\right)$ were calculated by Eq. (7) and (8), respectively.

$$
\begin{aligned}
& \mathrm{t}_{\mathrm{m}}=\frac{\int_{0}^{\infty} t E(t)}{\int_{0}^{\infty} E(t) d t}=\int_{0}^{\infty} t E(t) d t \\
& \sigma^{2}=\int_{0}^{\infty}\left(\mathrm{t}-\mathrm{t}_{\mathrm{m}}\right)^{2} \mathrm{E}(\mathrm{t}) \mathrm{dt}
\end{aligned}
$$

The exact variance $\left(\sigma_{\theta}^{2}\right)$ as in Eq. (9), which is the ratio of the variance to the square of the experimental mean residence time, is used to predict the dispersion number $\left(\frac{D}{u L}\right)$. The $\frac{D}{u L}$ is the dimensionless parameter that directly gives an indication of the flow regime. The value of one corresponds to the completely mixed, while the value of zero indicates the perfect plug-flow conditions.

$$
\sigma_{\theta}^{2}=\frac{\sigma^{2}}{t_{m}^{2}}=2\left(\frac{D}{u L}\right)-2\left(\frac{D}{u L}\right)^{2}\left[1-e^{-u L / D}\right]
$$

where $\mathrm{D}=$ dispersion coefficient $\left(\mathrm{m}^{2} / \mathrm{s}\right), \mathrm{u}=$ velocity gradient $(\mathrm{m} / \mathrm{s})$ and $\mathrm{L}=$ Flow distance $(\mathrm{m})$.

\section{Results and Discussions}

\subsection{Turbidity Removal by Jet Clarifier}

Effects of liquid flow rate and sludge blanket height on turbidity removal efficiency: Figure 3 illustrates the turbidity removal as a function of flow rates and sludge blanket heights. For the synthetic raw water, the efficiency was decreased when raising the flow rate. The highest efficiencies of $68 \%$ and $80 \%$ can be achieved at the flow rates of $40-70 \mathrm{~L} / \mathrm{hr}$ for the blanket heights of $10 \mathrm{~cm}$ and $25 \mathrm{~cm}$, respectively. Similar results were obtained from the actual raw water with the highest efficiency of $81 \%$ at $70 \mathrm{~L} / \mathrm{hr}$ and $25 \mathrm{~cm}$ height; therefore, they are not shown here. Moreover, $\mathrm{pH}$ of the treated water was in the neutral range $(7.0$ - 7.5) [19]. In addition, the efficiency of this jet clarifier was similar to the approximately $80 \%$ of the Samsen Water Treatment Plant 1, which uses a jet pulsator and sedimentation in a conventional rectangular tank for 6 hours $[20,21]$.

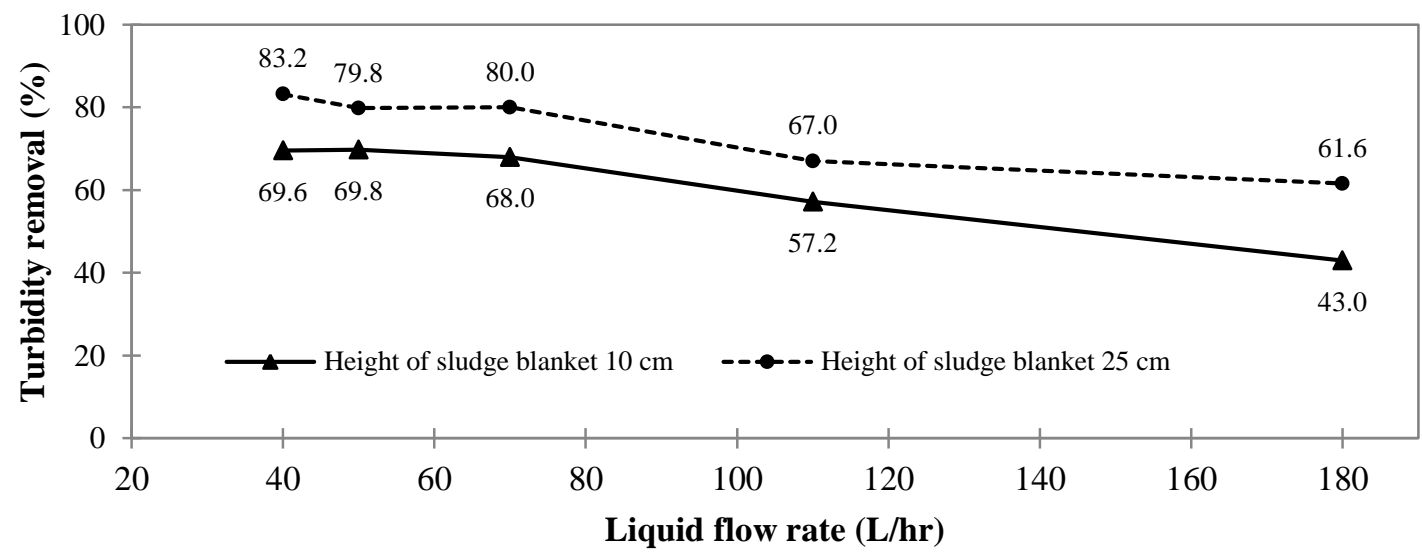

Fig. 3. Comparison of turbidity removal efficiency as a function of liquid flow rates.

In summary, the liquid flow rates and the sludge blanket heights were key factors in the design and operation due to their effects on efficiency. The optimal condition in this work can be suggested at the sludge blanket height of $25 \mathrm{~cm}$ and the liquid flow rate of $70 \mathrm{~L} / \mathrm{hr}$ (retention time of 197 minutes). Note that the lower efficiency of the jet clarifier compared to the jar test was a result of different operation modes, which are continuous and batch systems, respectively.

Effects of flow rate on the efficiency can be explained by the velocity gradient $(G)$ and retention time (t). The lower flow rates of $40 \mathrm{~L} / \mathrm{hr}$ and $50 \mathrm{~L} / \mathrm{hr}$ gave insufficient $\mathrm{G}$ for slow mixing but provided large retention time. This allowed particles to separate from water by settling resulting in the good efficiency. On 
the contrary, the jet clarifier was ineffective in the turbidity removal at the flow rates higher than $70 \mathrm{~L} / \mathrm{hr}$ due to its short retention time. Moreover, the height of the sludge blanket also affected the efficiency. As the cumulative sludge volume would be recirculated to the flocculation zone, it can increase the contact probability between particles and enhance the agglomeration of destabilized particles forming larger solid flocs $[1,11]$.

Effect of liquid flow rate on design parameters: Table 4 presents the parameters considered in this study at different operating conditions. The reasonable ranges of the liquid flow rates in this study suggested by the suitable $G$, t, and $G \cdot t$ values in the design criteria were 50,70 , and $110 \mathrm{~L} / \mathrm{hr}$. These flow rates were then applied to study the turbidity removal efficiency and effects of sludge blanket height.

Table 4. Operating conditions performed by various $G$, $t$ and $G \cdot t$ values.

\begin{tabular}{|c|c|c|c|c|c|c|c|}
\hline Method & $\begin{array}{l}\text { Liquid flow } \\
\text { rate }(\mathrm{L} / \mathrm{hr})\end{array}$ & Mechanism & $\begin{array}{c}G \\
\left(\mathrm{~s}^{-1}\right)\end{array}$ & $\begin{array}{c}\mathrm{t} \\
(\mathrm{s})\end{array}$ & $(G \cdot t)$ & $\begin{array}{l}\theta_{\text {sed }{ }^{\mathrm{a}}} \\
(\mathrm{hr})\end{array}$ & $\begin{array}{l}\theta_{\mathrm{Jet}^{\mathrm{b}}}{ }^{2} \\
(\mathrm{hr})\end{array}$ \\
\hline $\begin{array}{l}\text { Design } \\
\text { criteria* }^{*}\end{array}$ & - & $\begin{array}{l}\text { coagulation } \\
\text { flocculation }\end{array}$ & $\begin{array}{l}>350 \\
<5^{\mathrm{d}}\end{array}$ & $\begin{array}{c}1<\mathrm{t}<5 \\
1200-2400\end{array}$ & $\begin{array}{l}<1700^{c} \\
10^{4}-10^{5}\end{array}$ & $1-3$ & - \\
\hline \multirow{5}{*}{$\begin{array}{l}\text { Pilot } \\
\text { plant }\end{array}$} & 40 & $\begin{array}{l}\text { coagulation } \\
\text { flocculation }\end{array}$ & $\begin{array}{c}243.76 \\
0.562\end{array}$ & $\begin{array}{l}3.31 \\
3000\end{array}$ & $\begin{array}{c}807.68 \\
1686\end{array}$ & 4.66 & 5.49 \\
\hline & 50 & $\begin{array}{l}\text { coagulation } \\
\text { flocculation }\end{array}$ & $\begin{array}{c}340.67 \\
0.630\end{array}$ & $\begin{array}{l}2.65 \\
2400\end{array}$ & $\begin{array}{c}903.02 \\
1512\end{array}$ & 3.72 & 4.39 \\
\hline & 70 & $\begin{array}{l}\text { coagulation } \\
\text { flocculation }\end{array}$ & $\begin{array}{c}564.32 \\
0.743\end{array}$ & $\begin{array}{l}1.89 \\
1800\end{array}$ & $\begin{array}{l}1068.47 \\
1337.40\end{array}$ & 2.79 & 3.29 \\
\hline & 110 & $\begin{array}{l}\text { coagulation } \\
\text { flocculation }\end{array}$ & $\begin{array}{c}1111.65 \\
0.931\end{array}$ & $\begin{array}{l}1.20 \\
1200 \\
\end{array}$ & $\begin{array}{c}1339.4 \\
1117.20 \\
\end{array}$ & 1.86 & 2.19 \\
\hline & 180 & $\begin{array}{l}\text { coagulation } \\
\text { flocculation }\end{array}$ & $\begin{array}{c}2326.96 \\
0.937\end{array}$ & $\begin{array}{c}0.74 \\
789.6\end{array}$ & $\begin{array}{l}1713.37 \\
739.86\end{array}$ & 1.25 & 1.47 \\
\hline
\end{tabular}

Note: $\quad$ * Reference $[1,11,12,15]$;

a) Retention times of sedimentation zone

b) Retention times of jet clarifier

c) Design criteria for static mixer (noritake) in rapid mix for water treatment

d) Design criteria for fluidized bed (floc blanket clarifier)

From the result, the jet clarifier can be used for removing turbidity in the water treatment. In fact, it is a conceptually simple process, but complex in practice. The process design is mainly based on empirical rules and experience rather than on general design criteria [22]. As a result, the parameters affecting the performance should be thoroughly investigated. The hydrodynamic in the reactor, which relates to flow pattern in the reactor, is one among the important factors in a jet clarifier. Therefore, it was studied in detail by the residence time distribution (RTD) approach as in the next section.

\subsection{Residence Time Distribution (RTD) in Jet Clarifier Reactor}

In order to obtain a behavior off non-ideal reactor, both the non-ideal compartment model and the dispersion model must be taken from the RTD curve, it was performed using the excel soccer function. Four conductivity probes were placed in reactor at the check point $1-4$ (Fig. 1(b), CP $1-4$ ). The experiments were carried out under 4 conditions, which were 40,70 and $180 \mathrm{~L} / \mathrm{hr}$ with sludge blanket and $70 \mathrm{~L} / \mathrm{hr}$ without sludge blanket. Figure 4 shows the relations between $\mathrm{E}(\mathrm{t})$ and time under all conditions. 


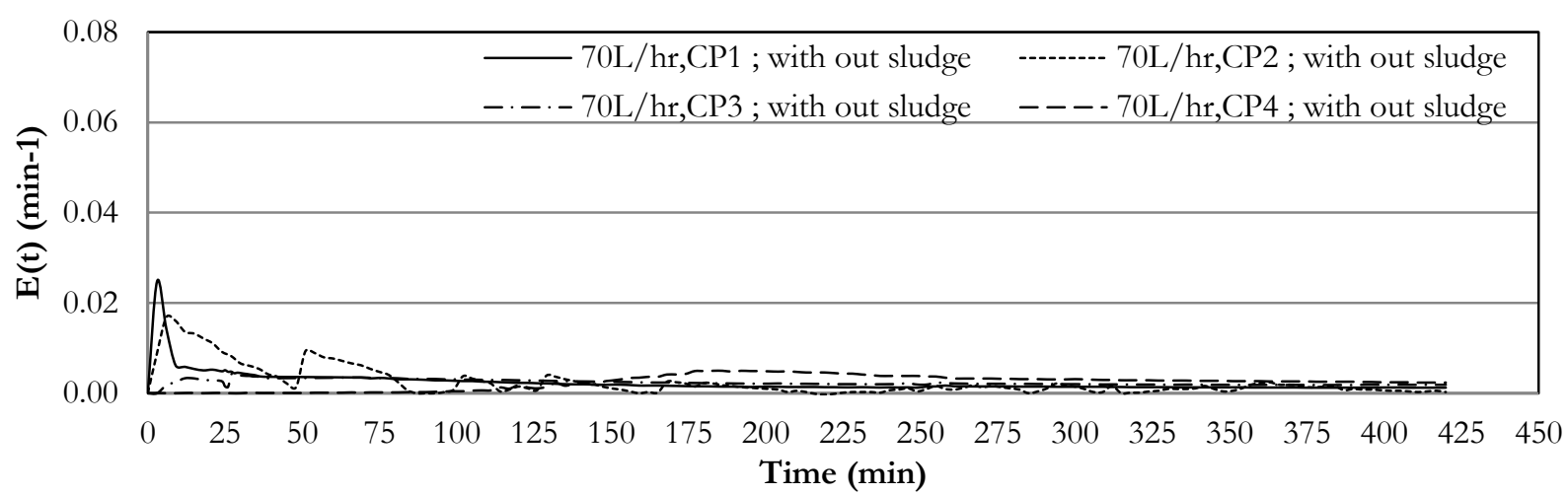

(a) E-curves as a RTD of flow rate $70 \mathrm{~L} / \mathrm{hr}$ without sludge blanket

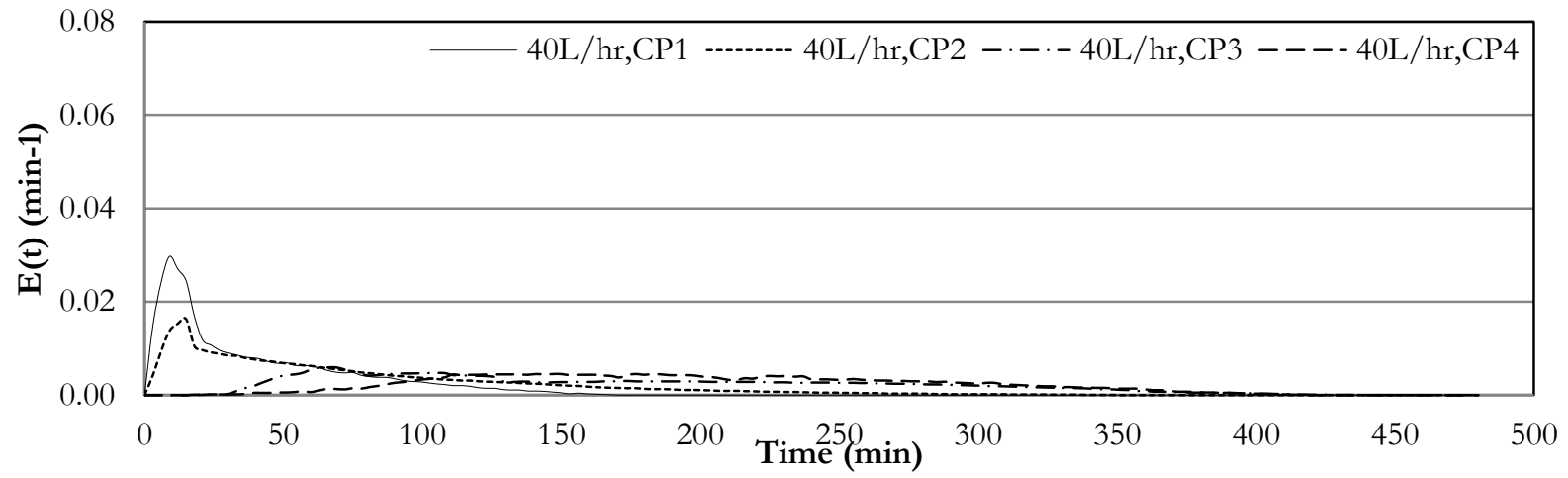

(b) E-curves as a RTD of flow rate $40 \mathrm{~L} / \mathrm{hr}$ with sludge blanket

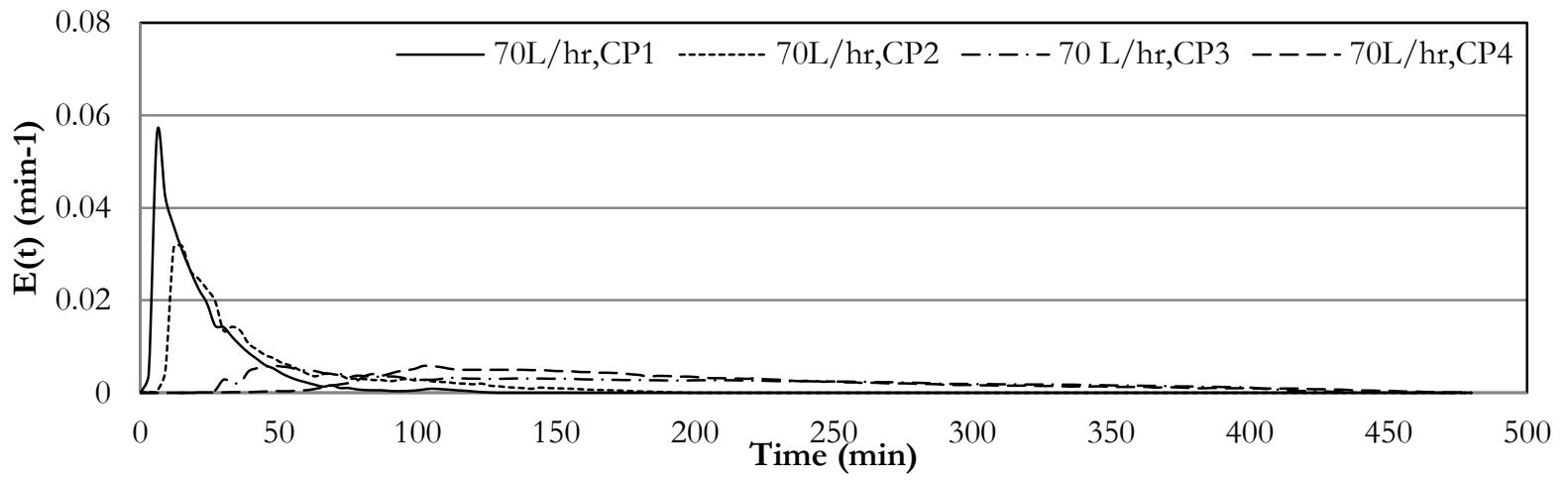

(c) E-curves as a RTD of flow rate $70 \mathrm{~L} / \mathrm{hr}$ with sludge blanket

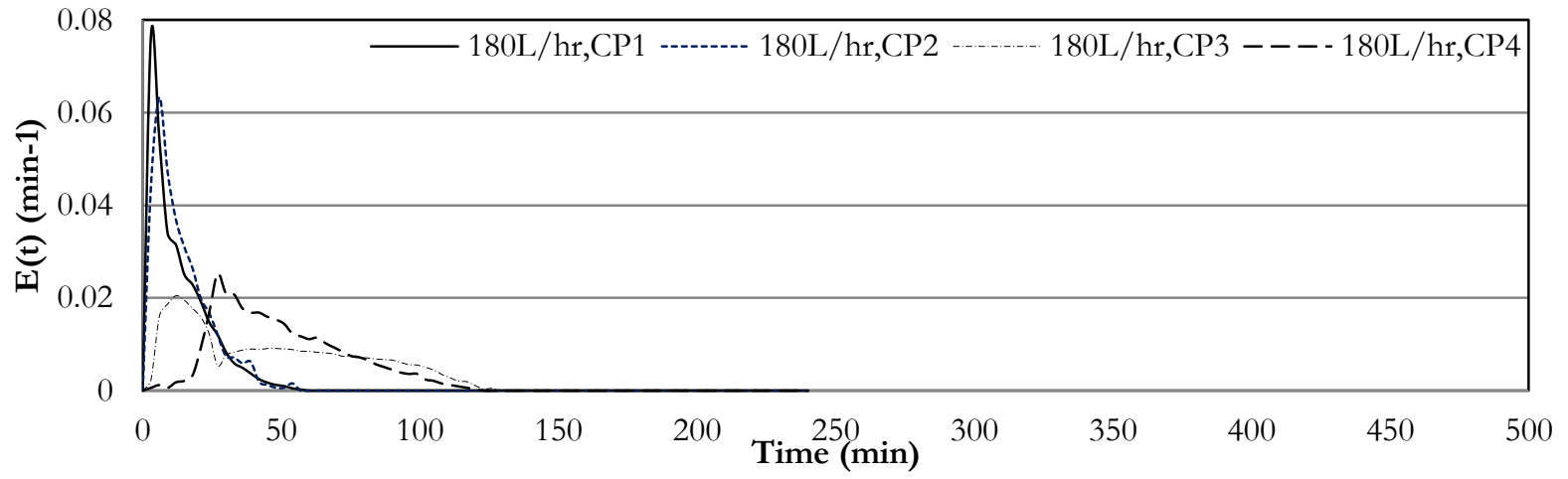

(d) E-curves as a RTD of flow rate $180 \mathrm{~L} / \mathrm{hr}$ with sludge blanket

Fig. 4. E-curves from RTD study in jet clarifier at different flow rates analyzed by method of moments and the compartment model.

Figure 4(a) illustrates the RTD result of flow rate $70 \mathrm{~L} / \mathrm{hr}$ without sludge blanket. Once tracer was feed into reactor, the probe at $\mathrm{CP} 1$ was detected the first inlet as plug flow behavior at 3 minutes. After the tracer flow pass CP1, it divided into two directions. The first part flowed consecutively to CP2 at 6 minutes, 
which also had plug flow behavior. Another part bypassed to CP3 as the tracer can be detected after 12 minutes. The first part at CP2 then returned downward following the flow pathway and, again, divided into two paths, including (1) flowed to CP1 and then recirculated between CP1 and CP2; (2) went to CP3 at 27 minutes ( 15 minutes after the bypass flow). All tracers at $\mathrm{CP} 3$ can flow to $\mathrm{CP} 4$ as the signal can be detected after 100 minutes.

With the sludge blanket at the same flow rate of $70 \mathrm{~L} / \mathrm{hr}$ (Fig. 4(c)), the flow pattern was quite similar to the case without the blanket. However, some differences can be observed. First, the bypass flow from CP1 to CP3 was much decreased with the sludge blanket. This could be seen at 30 minutes as the bypass peak at CP3 was very small comparing to Fig. 4(a). The second difference was the reduction of the recirculation from $\mathrm{CP} 2$ to $\mathrm{CP} 1$. No looping peak at $\mathrm{CP} 2$ can be observed with the presence of sludge. The sludge blanket can restrict the bypass from CP1 to CP3 and the circulation of CP2 back to CP1. In addition, the liquid flow rate also influenced the bypassing. As can be seen in Fig. 5(d), there was a bypass peak at 12 minutes for $180 \mathrm{~L} / \mathrm{hr}$ liquid flow rate, while the peak did not appear at $40 \mathrm{~L} / \mathrm{hr}$. Therefore, increasing the flow rate could induce more bypass flow.

Table 5. Mean residence time and $\frac{\mathrm{D}}{\mathrm{u}}$ of each flow rate.

\begin{tabular}{|c|c|c|c|c|c|}
\hline $\begin{array}{l}\text { Flow } \\
\text { rate } \\
(\mathrm{L} / \mathrm{hr})\end{array}$ & $\begin{array}{l}\text { Check } \\
\text { point }\end{array}$ & $\begin{array}{l}\text { Theoretical mean } \\
\text { residence time } \\
\text { (min) }\end{array}$ & $\begin{array}{l}\text { Experimental mean } \\
\text { residence time at operating } \\
\text { without sludge (min) }\end{array}$ & $\begin{array}{c}\text { Experimental mean } \\
\text { residence time at } \\
\text { optimum condition ( } \mathrm{min} \text { ) }\end{array}$ & $\frac{D}{u L}$ \\
\hline \multirow{4}{*}{40} & 1 & 2 & - & 13 & \multirow{4}{*}{0.11} \\
\hline & 2 & 55 & - & 71 & \\
\hline & 3 & 170 & - & 172 & \\
\hline & 4 & 364 & - & 203 & \\
\hline \multirow{4}{*}{70} & 1 & 1 & 137 & 8.5 & \multirow{4}{*}{0.16} \\
\hline & 2 & 32 & 108 & 41 & \\
\hline & 3 & 97 & 188 & 182 & \\
\hline & 4 & 208 & 260 & 200 & \\
\hline \multirow{4}{*}{180} & 1 & 0.5 & - & 12 & \multirow{4}{*}{0.48} \\
\hline & 2 & 12 & - & 13 & \\
\hline & 3 & 38 & - & 43 & \\
\hline & 4 & 81 & - & 42 & \\
\hline
\end{tabular}

Table 5 displays the RTD experimental mean residence time and variance. The $t_{m}$ were obviously greater than the theoretical one due to the recirculation in reactor. It should be noticed that at flow rate of $180 \mathrm{~L} / \mathrm{hr}$, the residence times at CP3 and CP4 were very close. Since the $t_{\mathrm{m}}$ of CP3 was the average value from the bypass from CP1 and the recirculation between $\mathrm{CP} 1$ and $\mathrm{CP} 2$, the mean residence time should be higher than expected value. The appearance of bypass peak at CP4 also resulted in lower $\mathrm{t}_{\mathrm{m}}$ value.

Furthermore, the $\frac{D}{u L}$ values in this study were in the range of $0.1-0.5$ indicating the plug flow condition as the $\frac{D}{u L}$ value was close to zero. The jet clarifier under the applied conditions can be considered as a plug flow reactor with partly mixed flow. The mixed flow regime can be enhanced by raising the flow rate as the $\frac{D}{u L}$ was increased. In detail, the flow pattern was diagnosed as the plug flow at CP1 to CP2 and then changed to the mixed flow at CP3 to CP4. This pattern was consistent with the mechanism of the jet clarifier with sludge recirculation [23]. However, the difference in the mean residence time between the experimental and theoretical values had to be mentioned. This could be a result of short circuit or bypass flow. To prove this discussion, the mass balance of flow in these check points was constructed with the supposed flow pattern in Figs. 5 and 6. Once the liquid feeding (F or $\mathrm{Q}_{\mathrm{L}}$ ) was introduced into the reactor, it passed CP1 and divided to CP2 and CP3 denoted as $\mathrm{Q}_{\mathrm{D}}$ and $\mathrm{Q}_{\mathrm{B}}$ with the quantities of a and b, respectively. The liquid that passed CP2 also separated into 2 paths including c $\left(\mathrm{Q}_{\mathrm{R}}\right)$ back to $\mathrm{CP} 1$ and direct flow d $\left(\mathrm{Q}_{\mathrm{J}}\right)$ to $\mathrm{CP} 3$. The liquid at $\mathrm{CP} 3$ can go to $\mathrm{CP} 4$ with some recirculation (r). 


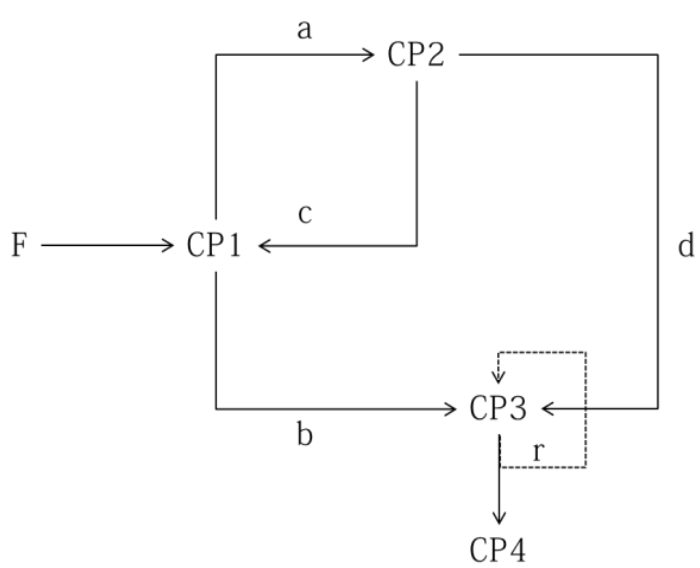

Fig. 5. Flow pattern in jet clarifier reactor.

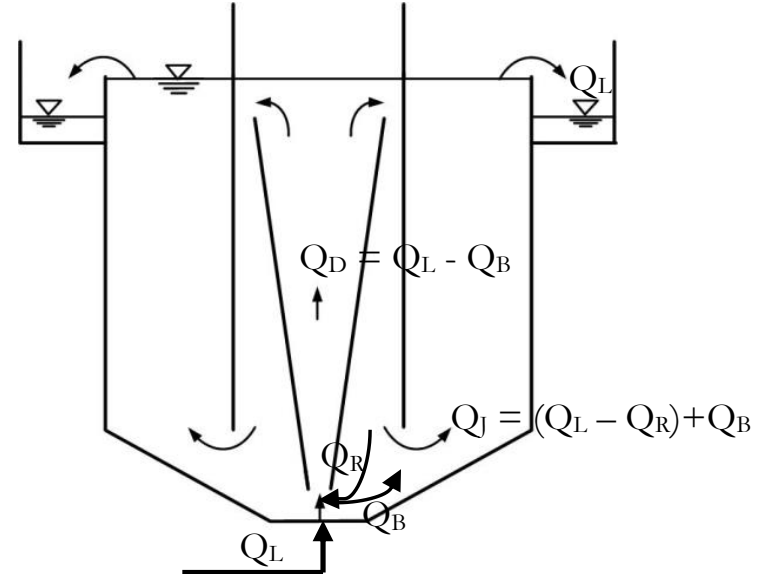

Fig. 6. Ways followed by the tracer inside the reactor.

Using this flow pattern and the assigned quantities, the mass balance equation between each point can be expressed as in Eq. (10) - (17). Unfortunately, this mass balance equation cannot take the dead zone of the system into account since the outlet tracer quantity at $\mathrm{CP} 4$ was used for solving these equations.

$$
\begin{gathered}
\mathrm{CP} 1=\mathrm{a}+\mathrm{b} \\
\mathrm{CP} 1=\mathrm{F}+\mathrm{c} \\
\mathrm{CP} 2=\mathrm{c}+\mathrm{d} \\
\mathrm{CP} 2=\mathrm{a} \\
\mathrm{CP} 3=\mathrm{b}+\mathrm{d}+\mathrm{r} \\
\mathrm{CP} 4=\mathrm{CP} 3-\mathrm{r} \\
\mathrm{F}=\mathrm{b}+\mathrm{d} \\
\mathrm{F}=\mathrm{CP} 4
\end{gathered}
$$

\begin{tabular}{|c|c|c|c|c|c|}
\hline \multirow{2}{*}{ Flow Fraction } & \multirow{2}{*}{$\begin{array}{l}\text { Symbol for } \\
\text { Fig. } 6\end{array}$} & \multirow{2}{*}{$\begin{array}{c}\text { Without Sludge } \\
70 \mathrm{~L} / \mathrm{hr}\end{array}$} & \multicolumn{3}{|c|}{ With Sludge } \\
\hline & & & $40 \mathrm{~L} / \mathrm{hr}$ & $70 \mathrm{~L} / \mathrm{hr}$ & $180 \mathrm{~L} / \mathrm{hr}$ \\
\hline $\mathrm{CP} 1$ to $\mathrm{CP} 2$ & $\mathrm{QD}_{\mathrm{D}}$ & 0.47 & 1.00 & 0.94 & 0.82 \\
\hline $\mathrm{CP} 1$ to $\mathrm{CP} 3$ & Qв & 0.53 & 0.00 & 0.06 & 0.18 \\
\hline $\mathrm{CP} 2$ to $\mathrm{CP} 1$ & $\mathrm{Q}_{\mathrm{R}}$ & 0.86 & 0.07 & 0.34 & 0.19 \\
\hline $\mathrm{CP} 2$ to $\mathrm{CP} 3$ & $\mathrm{Q}_{\mathrm{J}}$ & 0.14 & 0.93 & 0.66 & 0.81 \\
\hline
\end{tabular}

The quantities of each variable were correlated from area under the curve between concentration and time, which resulted in amount of tracer passing that point divided with liquid flow rate. Since the flow rate in reactor was constant, using the area to represent the quantities of flow passing each check point was reasonable. After solving Eq. (10) to (17), the fractions of flow between each check point were summarized in Table 6.

Table 6. Fraction of flow between each checkpoint.

From Table 6, the jet clarifier without sludge blanket had very high fraction of return from CP2 to CP1 (0.86) and also high bypass fraction from CP1 to CP3 (0.53). However, the return and the bypass fractions were respectively decreased to 0.34 and 0.06 for the same flow rate with sludge blanket in the reactor. The presence of sludge blanket can restrict the flow pathway and reduce the bypass and liquid recirculation resulting in the flow pathway similar to the design. Moreover, effects of flow rate can be clearly seen. At the flow rate of $40 \mathrm{~L} / \mathrm{hr}$, there was no bypass but it would get higher fraction as flow rate increased. Therefore, increasing flow rate can induce the bypass flow in reactor.

To enhance the turbidity removal, the increase of the flow rate to promote more recirculation should be considered. However, it could be compensated with the increased bypass flow. One should keep in mind that the increased of flow rate also resulted in shorter retention time, thus resulting in lower removal efficiency as the settling time could be insufficient [24]. In order to achieve the effective removal of turbidity, these factors have to be optimized. 


\section{Conclusion}

The results indicated that jet clarifier was effective for removing colloidal particles and suspended solids from water. The optimal conditions for the turbidity removal were found as summarized in Table 7 . Under the optimal condition, the turbidity removal efficiency of $80 \%$ was obtained.

It could be suggested that the jet clarifier could be applied instead of the conventional process since it requires less operating time and energy as well as smaller area but can provide similar efficiency as the conventional coagulation at the same overflow rate. The settling efficiency could be also enhanced by applying a settling plate or tube, which should be further studied in the future.

Table 7. Summary of the optimal design criteria of the jet clarifier with $25 \mathrm{~cm}$ sludge height.

\begin{tabular}{|c|c|c|c|c|c|c|c|c|}
\hline $\begin{array}{c}\text { Liquid } \\
\text { flow rate } \\
(\mathrm{L} / \mathrm{hr})\end{array}$ & $\begin{array}{l}\text { Coagulant } \\
\text { type }\end{array}$ & $\begin{array}{c}\text { Chemical } \\
\text { dose } \\
(\mathrm{mg} / \mathrm{L})\end{array}$ & Mechanism & $\underset{\left(\mathrm{s}^{-1}\right)}{\mathrm{G}}$ & $\begin{array}{c}\mathrm{t} \\
(\mathrm{s})\end{array}$ & $(G \cdot t)$ & $\begin{array}{l}\theta_{\text {sed }^{a}} \\
(\mathrm{hr})\end{array}$ & $\begin{array}{l}\theta_{\mathrm{Jet}^{\mathrm{b}}} \\
(\mathrm{hr})\end{array}$ \\
\hline 70 & $\begin{array}{l}\text { aluminium } \\
\text { sulphate }\end{array}$ & $20-30$ & $\begin{array}{l}\text { coagulation } \\
\text { flocculation }\end{array}$ & $\begin{array}{c}564.32 \\
0.743\end{array}$ & $\begin{array}{l}1.89 \\
1800\end{array}$ & $\begin{array}{l}1068.47 \\
1337.40\end{array}$ & 2.79 & 3.29 \\
\hline
\end{tabular}

Remarks: a) Retention time of the sedimentation zone; b) Retention time of the Jet clarifier.

From the RTD results, the jet clarifier under the applied conditions contained the plug flow reactor pattern in the coagulation zone and changed to a mixed flow pattern in the flocculation and settling zones. The increase of flow rate can enhance the recirculation resulting in the increased efficiency. However, this could lead to more bypass flow and shorter retention time, which would reduce the process performance. In addition, the presence of a sludge blanket plays a key role in the separation since it helped controlling the flow pattern as well as increasing a target for particle agglomeration.

It is a well-known fact that flow patterns strongly depend on flow rate. However, at the scale of this experimental device, the flow convective contributions induced by flow rate can greatly affect the flow pattern. In addition, shape and size of a buffer installed in a reactor can also influence the efficiency. The study in detail should be conducted on its effects on flow behavior and treatment efficiency. This could lead to the optimization of the operation for improved efficiency.

\section{Nomenclature}

$\begin{array}{ll}C_{i} & =\text { Initial turbidity (NTU) } \\ C_{f} & =\text { Final turbidity }(\mathrm{NTU}) \\ \rho & =\text { Liquid density }\left(\mathrm{kg} / \mathrm{m}^{3}\right) \\ \rho_{\mathrm{s}} & =\text { Particle or floc dencity }\left(\mathrm{kg} / \mathrm{m}^{3}\right) \\ \mathrm{C} & =\text { Floc volume concentration } \\ \mu & =\text { Dynamic viscosity of liquid }(\mathrm{kg} / \mathrm{m} \cdot \mathrm{s}) \\ \mathrm{U} & =\text { Velocity of liquid being stirred, or flowing in flocculator }(\mathrm{m} / \mathrm{s})\end{array}$

\section{Acknowledgements}

This work was financed by the Chulalongkorn University Fund, Department of Environmental Engineering, Faculty of Engineering, Chulalongkorn University.

\section{References}

[1] G. Degremont, Water Treatment Handbook, vol. 2, 6 $6^{\text {th }}$ ed. France: Lavoisier Publishing, 1991.

[2] I. C. Tse, K. Swetland, M. L. Weber-Shirk, and L. W. Lion, "Fluid shear influences on the performance of hydraulic flocculation systems," Water Research, vol. 45, pp. 5412-5418, 2011.

[3] S. R. Qasim, E. M. Motley, and G. Zhu, "Coagulation, flocculation and precipitation," in Water Works Engineering: Planning, Design, And Operation. New Jersey, USA: Prentice Hall, 2000, pp. 229-300.

[4] M. X. Zheng, K. J. Wang, J. E. Zuo, Z. Yan, H. Fang, and J. W. Yu, "Flow pattern analysis of a fullscale expanded granular sludge bed-type reactor under different organic loading rates," Bioresource Technology, vol. 107, pp. 33-40, 2012. 
[5] A. H. Essadki, B. Gourich, Ch. Vial, and H. Delmas. "Residence time distribution measurements in an external-loop airlift reactor: Study of the hydrodynamic of the liquid circulation induce by the hydrogen bubles," Chemical Engineering Science, vol. 66, pp. 3125-3132, 2011.

[6] A. Bittante, J. García-Serna, P. Biasi, F. Sobrón, and T. Salmi, "Residence time and axial dispersion of liquids in Trickle Bed Reactors at laboratory scale," Chemical Engineering Journal, vol. 250, pp. 99-111, 2014.

[7] Y. Gao, F. J. Muzzio, and M. G. Ierapetritou, "A review of the Residence Time Distribution (RTD) applications in solid unit operations," Powder Technology, vol. 228, pp. 416-423, 2012.

[8] A. T. Harris, J. F. Davidson, and R. B. Thorps, "Particle residence tine distribution in circulating fulidise beds," Chemical Engineering Science, vol. 58, pp. 2181-2202, 2003.

[9] Performance Statistic of Water Quality. [Online]. Available: http://www.mwa.co.th/ewtadmin/ewt/mwa_internet_eng/ewt_news.php?nid=97 [Accessed: Dec 2011].

[10] D. Bouyer, C. Coufort, A. Linéa, and Z. Do-Quang, "Experimental analysis of floc size distributions in a 1-L jar under different hydrodynamics and physicochemical conditions," Journal of Colloid and Interface Science, vol. 292, pp. 413-428, 2005.

[11] S. Kawamura, Integrated Design and Operation of Water Treatment Facilities, $2^{\text {nd }}$ ed. USA: John Wiley \& Sons, INC, 2000.

[12] T. D. Reynolds and P. A. Richards, Unit Operations And Processes In Environmental Engineering, $2^{\text {nd }}$ ed. USA: PWS Publishing Company, 1996.

[13] APHA, AWWA, and WEF, Standard Methods for the Examination of Water \& Wastewater, 21 ${ }^{\text {st }}$ ed. Washington, DC: American Public Health Association, 2005.

[14] The Designing of Static Mixer (Noritake) In Rapid Mix for Water Treatment. [Online]. Available:http://www.tumcivil.com/engfanatic/content/upload/File/mwa/sta_000e.pdf [Accessed: Jan 2012].

[15] M. A. Hughes, "Coagulation and flocculation Part 1-2," in Solid-liquid separation, $4^{\text {th }}$ ed. L. Svarovsky, Eds. Pondicherry, India: Integra Software Services Pvt Ltd., 2000, pp. 104-165.

[16] H. S. Fogler, Elemmts of Chemical Reaction Engineering, 4th ed. USA: Pearson Education, 2013.

[17] O. Levenspiel, Chemical Reaction Engineering, 3 ${ }^{\text {td }}$ ed. USA: John Wiley \& Sons, 1999.

[18] R. M. Alkhadder, P. R. Higgins, D. A. Phipps, and R. Y. G. Andoh, "Residence tine distribution of a model hydrodynamic vortex separator," Urban Water, vol. 3, pp. 17-24, 2001.

[19] R. Chamnanmor, P. Painmanakul, and C. Puprasert, "Study of in-line coagulation and flocculation processes for turbidity removal: Experimental approaches," in Proc. The 5th AUN/SEED-Net Regional Conference on Global Environment, Bundung, Indonesia, 2012, p. 25.

[20] Samsen Water Treatment Plant, "Water Quality Report, Report of the water quality analysis system," MWA, Bangkok, Thailand, 2009-2012.

[21] Samsen Water Treatment Plant Engineering Group, "Existing design capacities and loadings report of the Samsen Water Treatment Plant Engineering Group," MWA, Bangkok, Thailand, 2002.

[22] P. R. López, A. G. Lavín, M. M. M. López, and J. L. B. de las Heras, "Flow models for rectangular sedimentation tanks," Chemical Engineering and Processing, vol. 47, pp. 1705-1716, 2008.

[23] S. D. Lin, Water and Wastewater Calculations Manual, $2^{\text {nd }}$ ed. USA: The McGraw-Hill, 2007.

[24] A. Koohestanian, M. Hosseini, and Z. Abbasian, "The separation method for removing of colloidal particles from raw water," American-Eurasian J. Agric. \& Environ. Sci., vol. 2, no. 4, pp. 266-273, 2008. 